\title{
Isolation and cultivation of planktonic freshwater microbes is essential for a comprehensive understanding of their ecology
}

\author{
Michaela M. Salcher*, Karel Šimek \\ Biology Centre CAS, Institute of Hydrobiology, Na Sádkách 7, 37005 České Budějovice, Czech Republic
}

\begin{abstract}
Representative model organisms form the basis on which biology is constructed, and pure cultures offer many opportunities for discovery. However, our view of the importance of axenic cultures changed dramatically at the turn of the last century upon realizing that the majority of environmentally relevant microbes still remains uncultured. The sequencing revolution has led us to a point where we can identify the microbial world in which we live, but many questions remain regarding the autecology of planktonic microbes and their interactions with their environment. Thus, it is essential to isolate and cultivate the key microbial players to gain a deeper insight into their ecology. If the past is a guide, the way forward in confronting the so-called 'great plate count anomaly' is the use of more subtle and refined approaches to culturing, using a number of methods and processes that are now becoming available. The vast amount of information accumulated from genome sequencing alone has yet to result in the isolation of the most important and abundant microbes of aquatic systems. We highlight the merits of pure cultures and discuss the critical need to integrate information from a variety of different sources to isolate planktonic microbes. We also describe how to culture bacteria of interest with a full cycle isolation approach based on targeted enrichment and illustrate the benefits of pure cultures with 2 examples of isolated representatives of freshwater Betaproteobacteria.
\end{abstract}

KEY WORDS: Autecology - Axenic cultures · Dilution to extinction · Ecophysiology · Genomics · Isolation of freshwater microbes · Targeted enrichment

\section{INTRODUCTION}

Recent advances in sequencing and improved single-cell and microscopic imaging techniques suggest that the future of aquatic microbial ecology is largely based on (meta-)omics and in situ single-cell approaches (Stepanauskas 2012, Temperton \& Giovannoni 2012, Blainey 2013, Son et al. 2015). Environmental meta-omics are undoubtedly important to gain insight into thus far unknown processes and functions of aquatic microbes (Rinke et al. 2013, VilaCosta et al. 2013, Ghylin et al. 2014), and single-cell

*Corresponding author: michaelasalcher@gmail.com techniques allow for a precise quantification and/or functional allocation of individual cells or populations (Amann \& Fuchs 2008, Musat et al. 2008, Stocker \& Seymour 2012, Salcher et al. 2013). The main advantages of these methods are their in situ characteristics, i.e. the natural environment is not or only slightly disturbed during sampling; moreover, they do not rely on cultures and can be combined with experimental approaches.

However, it is still essential to isolate and cultivate the key players of aquatic systems to get 'a holistic picture' of their ecology (Giovannoni \& Stingl 2007).

() The authors 2016. Open Access under Creative Commons by Attribution Licence. Use, distribution and reproduction are unrestricted. Authors and original publication must be credited. 
At the turn of the last century, at what can be termed as the nascent time for the '-omics' age, the realization that $>99 \%$ of the microbial world remains uncultured came as a surprise in the dynamic field of microbiology (Staley \& Konopka 1985, Amann et al. 1995). Some decades ago, only microbes that are able to grow in media with high concentrations of organic nutrients and carbon sources had been cultivated (Jannasch 1958, Allen et al. 1983, Hahn \& Höfle 1998). However, such copiotrophic microbes (e.g. Vibrio spp., Pseudomonas spp.) do not necessarily represent the natural community in freshwaters where oligo- to mesotrophic conditions prevail. Moreover, as most aquatic bacteria and archaea are planktonic, they do not readily grow on agar plates, although there are some exceptions (O'Sullivan et al. 2004, Cousin et al. 2008, Hutalle-Schmelzer et al. 2010, Jogler et al. 2011, Watanabe et al. 2012). Thus, these cultivation approaches selected mainly for rare copiotrophic taxa, a phenomenon called 'the great plate count anomaly' (Staley \& Konopka 1985, Amann et al. 1995). Further improvements in cultivation techniques, however, have led to the isolation of environmentally abundant oligo- to mesotrophic microbes (Fig. 1) of freshwater (Bruns et al. 2003, Hahn 2003, Hahn et al. 2003, Gich et al. 2005) and marine systems (Schut et al. 1997, Rappé et al. 2002, Könneke et al. 2005). As solid media proved to be inefficient for the isolation of obligate planktonic microbes, most cultivation efforts were made in liquid media and a dilution of the inoculum to 0.5-5 cells sample ${ }^{-1}$ to obtain monoclonal cultures (dilution to extinction, serial dilution; Connon \& Giovannoni 2002, Bruns et al. 2003, Selje et al. 2005, Stingl et al. 2007). The main improvements for a successful isolation of microbes concerned the culti-

Fig. 1. Maximum likelihood tree of 16S rRNA genes of selected heterotrophic bacteria that were isolated from freshwaters and their affiliation to typical freshwater lineages proposed by Newton et al. (2011). The genera Limnohabitans and Ca. Methylopumilus (highlighted in bold) are described in more detail in the main text. The scale bar at the bottom represents $10 \%$ sequence divergence

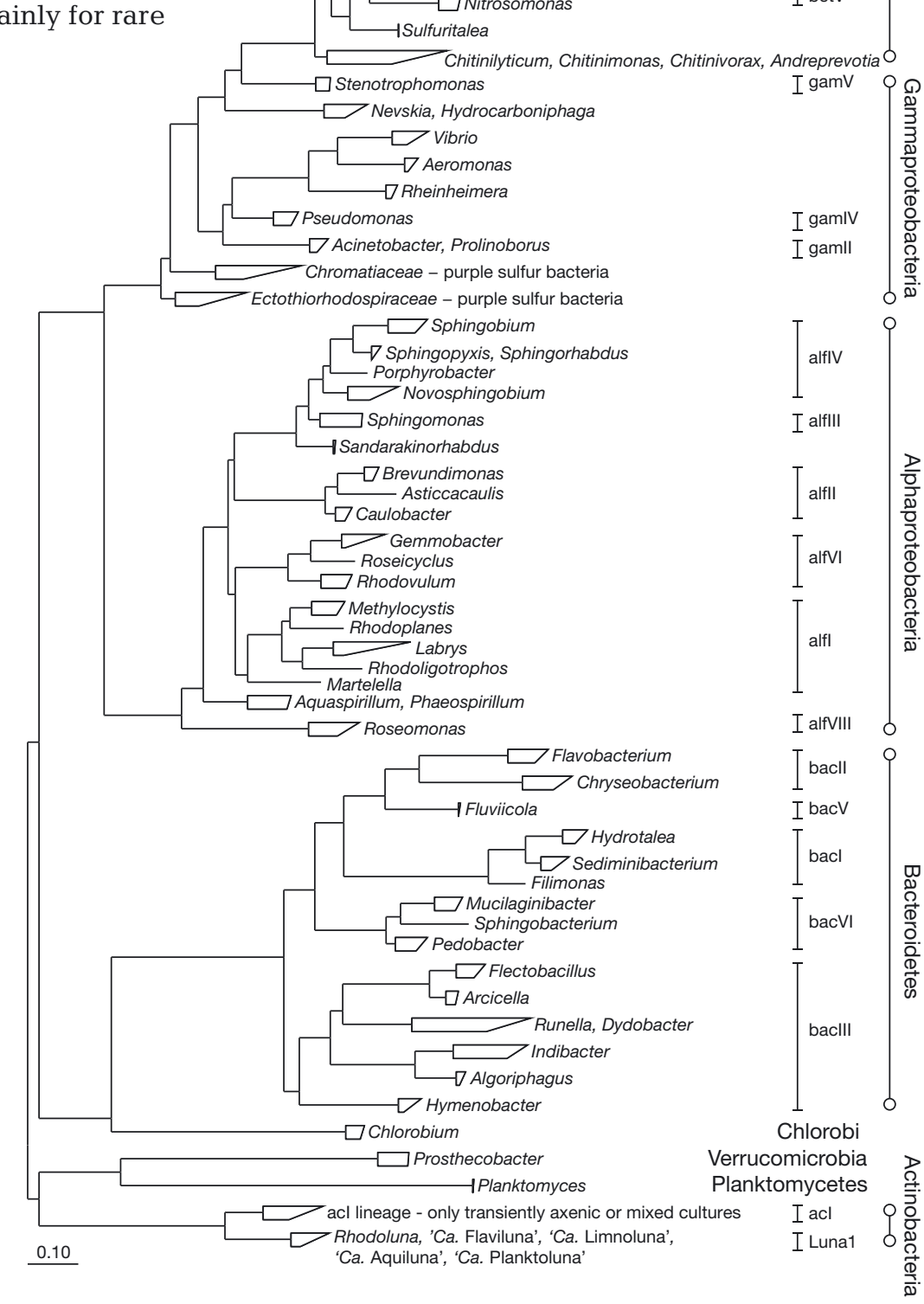


vation media that were either synthetic and adapted to natural oligotrophic conditions or sterilized lake water amended with only low amounts of nutrients, carbon sources, and vitamins (Bruns et al. 2003, Page et al. 2004). Another isolation strategy for very small microbes is the so-called filtration-acclimatization method invented by Hahn et al. (2003), where water samples are filtered through $0.2 \mu \mathrm{m}$ membranes to remove larger organisms and the remaining ultramicrobacteria are adapted to higher concentrations of complex media in a stepwise manner. This method proved to be effective for the isolation of numerous freshwater strains affiliated with Polynucleobacter spp. and the Luna lineage of Actinobacteria (Hahn 2003, Hahn et al. 2003). Likewise, a selective enrichment of the target organisms prior to isolation can significantly increase the cultivation success. Such an enrichment of Sphingomonadaceae (Alphaproteobacteria) was achieved by the addition of growth inducers to minimal medium (Gich et al. 2005, Jogler et al. 2011) or by the addition of humic matter or phenol to sterile lake water (Hutalle-Schmelzer et al. 2010). The latter attempt also enabled enrichment and subsequent isolation of a wide range of different microbes from humic lakes (Hutalle-Schmelzer et al. 2010). Microbes which grow mainly on algal-derived organic matter (e.g. Flavobacteriaceae, Comamonadaceae) can be enriched upon addition of algal extracts or exudates to the cultivation medium or might be isolated at times of algal blooms (Zeder et al. 2009, Hahnke et al. 2015, Salcher et al. 2016). Finally, fast-growing microbes like Limnohabitans spp. or Flavobacterium spp. can also be enriched in predator-free dilution cultures (Kasalický et al. 2013, Neuenschwander et al. 2015). One example of a successful isolation of such fast-growing bacteria (Limnohabitans spp.) is described in more detail below.

\section{POSSIBLE REASONS WHY SOME OBLIGATE PLANKTONIC MICROBES STILL RESIST CULTIVATION}

A large number of prokaryotes isolated from freshwaters have been validly described (Fig. 1). However, the majority of these taxa have been isolated on agar plates or in rich media and therefore represent typical copiotrophs or 'tychoplankton,' i.e. they are transient or not very abundant members of the plankton, as signature sequences of these microbes have rarely been recovered from environmental samples (Newton et al. 2011). Notably, a valid description of a novel species requires a deposition of the type strain in 2 public culture collections to make it available to other scientists (Kämpfer et al. 2003), and a prerequisite for the deposition is a successful cultivation in synthetic media and/or on agar plates. Obligate planktonic prokaryotes that are hard to cultivate rarely fall into this category. For example, the most abundant marine microbes-the SAR11 clade-are still not validly described ('Ca. Pelagibacter ubique') and it took more than $10 \mathrm{yr}$ from the isolation of the first SAR11 strains to a successful cultivation in defined synthetic medium (Rappé et al. 2002, Carini et al. 2013). Only recently, a number of environmentally relevant planktonic freshwater taxa have been brought to culture (Fig. 1), e.g. Limnohabitans spp. (Hahn et al. 2010a,b, Kasalický et al. 2010, 2013), Polynucleobacter spp. (Hahn et al. 2009, 2010c, 2011, 2012), 'Ca. Methylopumilus spp.' (Salcher et al. 2015), Sphingomonas spp. (Hutalle-Schmelzer et al. 2010, Jogler et al. 2011, Salka et al. 2014), Rhodoluna spp. (Hahn et al. 2014), Fluviicola spp. (O'Sullivan et al. 2005), and Flavobacterium spp. (Cousin et al. 2008, Ali et al. 2009, Sack et al. 2011, Lee et al. 2012).

The most abundant planktonic freshwater microbes, i.e. Actinobacteria of the acI-lineage and Alphaproteobacteria of the LD12 lineage (the freshwater sister group of SAR11), however, still resist axenic cultivation. Both lineages are of very small cell size (ultramicrobacteria), have streamlined genomes, and follow a typical oligotrophic lifestyle with adaptations to very low nutrient and carbon concentrations (Salcher et al. 2011b, ZarembaNiedzwiedzka et al. 2013, Ghylin et al. 2014). Streamlined oligotrophs are typically non-motile, seem to be only slowly growing, and are characterized by poor metabolic plasticity, i.e. they are unable to acclimate to resource-rich conditions. However, they are extremely competitive in nutrient-poor conditions of natural aquatic habitats and seem to at least partially escape predation by protists (Yooseph et al. 2010). These ecological features together with specific nutritional requirements and potential auxotrophies for unknown compounds may have hampered successful isolation thus far. For example, although members of the acI lineage have been repeatedly isolated or enriched via dilution to extinction (Gich et al. 2005, Selje et al. 2005, M. M. Salcher unpubl. data), the initially dense monocultures stopped growing when propagated to fresh sterile lake water medium, and all attempts to keep cultures alive have so far been unsuccessful 
(M. M. Salcher unpubl. data). This hints at very specific adaptations to the environmental conditions at the time of isolation, such as the presence of vital unknown growth substrates. Nevertheless, biomass of these transiently cultivable microbes can be used for whole-genome sequencing, thus providing information about specific metabolic pathways that might help to refine potential cultivation media (M. M. Salcher unpubl. data). AcI Actinobacteria can be grown in co-cultures for several generations (Jezbera et al. 2009, Garcia et al. 2014), and 1 species has been so far described as Candidatus ('Ca. Planktophila limnetica,' Jezbera et al. 2009). It is thus very likely that acI Actinobacteria live in close contact and metabolic interconnectedness with cooccurring microbes, i.e. they depend on metabolites provided by others (Garcia et al. 2015, Garcia 2016). Actinobacteria of the Luna lineage on the other hand can be grown axenically in rich complex medium, although they are also of very small size and have reduced genomes (Hahn et al. 2003, 2014, Hahn 2009).

\section{BENEFITS OF PURE CULTURES}

\section{High-quality reference genomes}

Whole-genome sequencing and assembly is much easier and cheaper from monocultures than from mixed assemblages or single amplified cells (SAGs), and unbiased high-quality reference genomes can only be produced from axenic cultures. Genomes assembled from metagenomic reads (MAGs) are always a composite of closely related taxa, as it is simply impossible to reconstruct genomes of individual strains in a mix of co-existing genotypes (Temperton \& Giovannoni 2012). SAGs, on the other hand, are intrinsically incomplete because of difficulties in the flow cytometric sorting, whole-genome amplification, and sequencing of DNA from single cells (Woyke et al. 2011, Clingenpeel et al. 2014). Therefore, it cannot be assessed whether particular genes or pathways are indeed absent or incomplete in SAGs and whether particular genomic traits are specific for single genotypes in MAGs.

\section{Reference for meta-omics and detection of different genotypes in nature}

Closed high-quality genomes from axenic cultures can serve as references for a variety of meta-omics approaches and for the design of specific primers and probes (Fig. 2). Indeed, fragment recruitment of metagenomic reads to full genome sequences has been repeatedly used to identify hypervariable regions or metagenomic islands hinting at a high level of microdiversification within closely related strains in the environment (Rodriguez-Valera et al. 2009, Cordero \& Polz 2014, Thrash et al. 2014). Genome sequences can also be retrieved from metatranscriptomes and -proteomes (Fig. 2); a mapping of reads gives vital information on transcribed genes under different environmental conditions and can shed light on their role in the environment. For example, this was demonstrated for the abundant marine bacterium Planktomarina temperata during a phytoplankton bloom (Voget et al. 2015). The design and testing of strain- or lineage-specific probes for fluorescence in situ hybridization (FISH) or specific primers

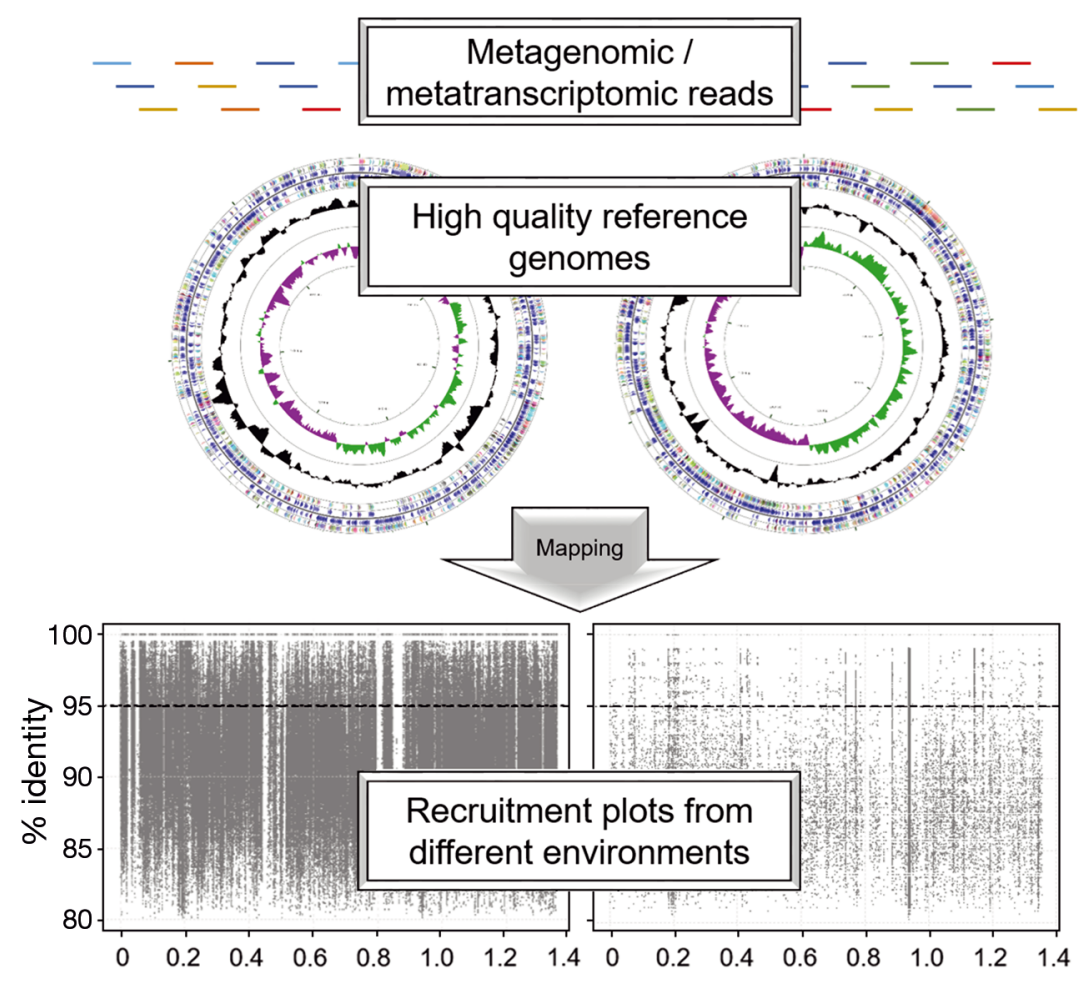

Fig. 2. Workflow for the usage of high-quality genomes from isolates as a reference for meta-omics. Fragment recruitment of metagenomic (left) and metatranscriptomic (right) reads to full genome sequences provides valuable information on the numerical relevance and potential microdiversification of different genotypes 


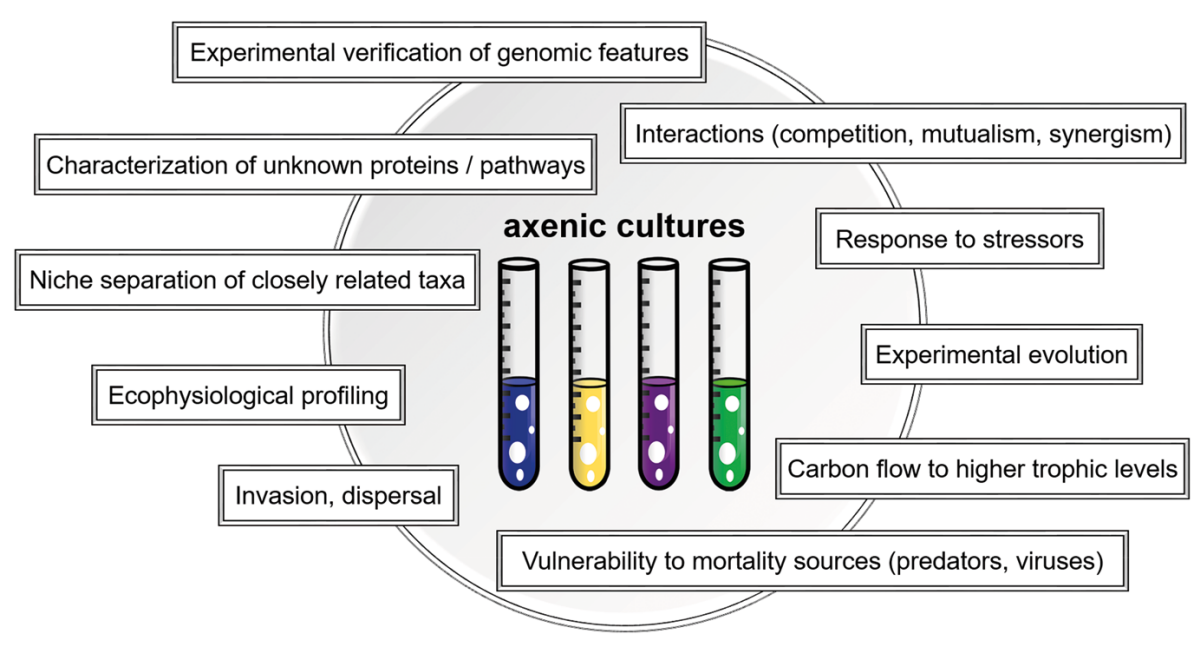

Fig. 3. Ideas for possible experiments with axenic cultures of freshwater microbes

for qPCR (Ramachandran \& Walsh 2015) and related applications (e.g. reverse line blot hybridization, RLBH: Jezbera et al. 2011; terminal restriction fragment length polymorphism: Paver et al. 2015) is straightforward from genomic data from cultures. Such primers or probes facilitate investigations of the abundance of cultured taxa in different ecosystems and can be used to test for microdiversification, habitat preferences, and seasonal dynamics of closely related strains.

\section{Autecology studies}

Metabolic and ecophysiological traits of different taxa can be easily examined with cultures, e.g. specific growth rates, substrate and nutrient requirements, temperature and salinity optima, etc. (e.g. Hahn \& Pöckl 2005, Ali et al. 2009, Kasalický et al. 2013). Although the genomic potential of uncultivated microbes can also be assessed with metaomics and SAGs, the mere presence or - in the case of (meta-)transcriptomics - expression of functional genes should not be over-interpreted, as it sometimes gives only limited information about specific ecophysiological functions in the target microbes. Single-cell methods can provide insights into the in situ substrate acquisition of microorganisms; however, they are usually restricted to a few substrates and are very laborious (Wagner et al. 2006, Salcher et al. 2013). Moreover, closely related strains of the same species or genus might differ in ecophysiological properties, making meta-omic and FISH-based analyses complicated due to the limited taxonomic resolution of these methods. Thus, autecological studies of cultured microbes provide much more detail and are also easier and faster to do. Functional postgenomic analyses (transcriptomics, proteomics, or metabolomics) of genome-sequenced strains growing under different conditions can help to identify their metabolic capacities (Zech et al. 2009, Smith et al. 2013)

\section{Experimental approaches and hypothesis testing}

Numerous laboratory or in situ experiments can be set up with axenic cultures (Fig. 3). Ecophysiological profiling of different strains can be combined with '-omics' (e.g. transcriptomics, proteomics) and thus give valuable insights in the regulation of central metabolism under different cultivation regimes (Sowell et al. 2008, Zech et al. 2009, Steindler et al. 2011, Smith et al. 2013). One big challenge in microbial genomics is that a large fraction of genes cannot be assigned to a specific function (ca. 20-30\%). Such genes or proteins of unknown function can be either characterized by detecting homologues in closely related organisms or by experimental evidence from cultures (e.g. via gene overexpression), although this is very laborious and time consuming. However, only the latter can ultimately identify unknown or unexpected metabolic pathways. For example, the genome of 'Ca. Pelagibacter ubique' encodes an unusual glycine-riboswitch that is essential for the central carbon metabolism (Tripp et al. 2009). Several 'Ca. Pelagibacter ubique' genomes have been screened for other unexpected metabolic pathways, and accompanying experimental work uncovered that these microbes are 'methylovores,' i.e. they can 
oxidize 1-carbon $\left(\mathrm{C}_{1}\right)$ compounds for energy generation (Sun et al. 2011). Such genome-assisted studies of laboratory cultures can also test for specific hypotheses that were generated during genome analyses or field investigations, e.g. adaptations to different substrates, temperatures, or salinity regimes (e.g. Hahn \& Pöckl 2005, Salcher et al. 2015). Finally, interactions between different organisms like interand intraspecific competition for limiting nutrients and substrates, commensalistic, mutualistic, or synergistic effects (e.g. Jagmann et al. 2010, GonzálezTorres et al. 2015), as well as the vulnerability to different mortality sources (grazing by protists, viral lysis) and potential microbial defense mechanisms can be addressed with isolates (Fig. 3). Predators or phages can be identified and isolated by using cultures as prey or hosts (Šimek et al. 2013, Zhao et al. 2013) and allow a detailed analysis of the fate of distinct taxa and their role in the carbon transfer to higher trophic levels. Other experimental approaches might target the response of different taxa to stressors (e.g. salinity, UV irradiation, antibiotics), invasion, dispersal, and adaptations to new environments (Horňák \& Corno 2012, Hall \& Corno 2014). To sum up, the list of potential experiments that can be set up with cultures is almost endless. Examples of 2 bacterial taxa (Limnohabitans spp. and 'Ca. Methylopumilus spp.') that were used in several experimental approaches are described in detail below.

\section{Establishment of new taxa}

A valid description of new taxa is only possible if strains can be easily cultivated in monocultures in synthetic media and/or on agar plates and is thus hardly practicable for obligate planktonic oligotrophs (see above). However, a proposal as Candidatus, i.e. taxa that cannot be described in sufficient detail to warrant establishment of a novel taxon, circumvents the strict rules of the bacteriological code and might be applicable for microbes that are hard to isolate and grow (Murray \& Stackebrandt 1995). Both options, the proposal of a new taxon or a Candidatus, enable a better description and formal naming of environmental relevant genera and species and should include a list of ecological, phenotypic, and genotypic traits. Consistent naming of closely related microbes might also help to improve the quality of public sequence databases that include so far mainly 'uncultivated bacteria' and to make straightforward cross-study comparisons (Newton et al. 2011).

\section{Establishment of new model systems for different types of freshwater microbes}

There is a need for more and better model organisms from freshwaters, i.e. all broadly defined ecotypes of freshwater microbes should have at least 1 cultivated representative serving for experimental studies and genetic engineering. While specialized microbes that play vital roles in the $\mathrm{S}, \mathrm{N}, \mathrm{CH}_{4}, \mathrm{Fe}$, or $\mathrm{H}$-cycle (e.g. sulfur oxidizers and reducers, nitrifying and denitrifying bacteria) have many cultivated taxa, model systems for the numerically dominant planktonic microbes that degrade different types of dissolved organic carbon (aerobic chemo-organoheterotrophs) are still rare. Thus, more planktonic microbes need to be isolated to get additional model systems, as not only the pool of dissolved organic matter but also their potentially specialized degraders are very diverse.

\section{HOW TO ISOLATE PLANKTONIC MICROBES? THE 'FULL CYCLE ISOLATION APPROACH' BASED ON TARGETED ENRICHMENT}

Analogous to the 'full cycle rRNA approach' (Amann et al. 1995) and the 'full cycle metagenomics approach' (Bodrossy 2015), we propose a 'full cycle isolation approach' that builds on ecological data gained from exploratory studies (Fig. 4). Genome sequences from MAGs or SAGs are a backbone for this approach, but data might also derive from temporal or spatial quantification of microbes in different environments, from in situ experiments, in situ ecophysiology studies (e.g. MAR-FISH, metatranscriptomics, stable isotope probing; Wagner et al. 2006, Wagner 2009, Franzosa et al. 2015), or any other method that gives specific hints on the ecology of the target microbes. Basically every published article addressing the organism of interest adds another piece of information to this composite ecological picture and might help to identify factors that stimulate its growth. These ecological features can be used for targeted enrichment of the preferred organisms in manifold ways: raw water samples can be amended with specific substrates (e.g. algal extracts for Flavobacteriaceae, humic matter for Sphingomonadaceae, methanol for Methylophilaceae; see 'Introduction' for details and more examples), or a synthetic cultivation medium can be designed based on reconstructed metabolic pathways. Other means to enrich the target microbes in natural samples include food web manipulations (e.g. the addition or removal of bac- 


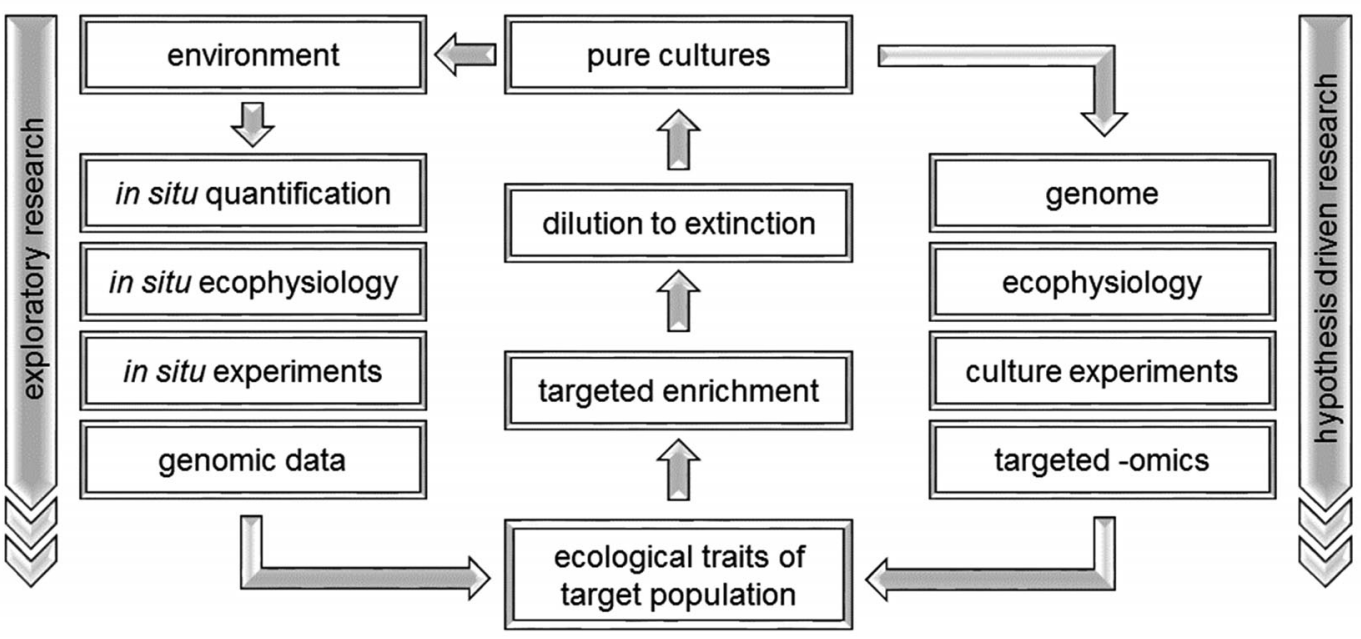

Fig. 4. Summary of the 'full cycle isolation approach' for a targeted isolation of microbes

terivorous predators), physical exclusion of bigger organisms (filtration through 0.2 or $0.45 \mu \mathrm{m}$ membranes), or flow cytometric sorting of distinct populations. One should keep in mind that targeted enrichment is a trial-and-error approach that might sometimes lead to unexpected results. However, successful enrichments can subsequently be purified to clonal cultures by dilution to extinction. In addition, the design of new imaginative growth media can also be based on the interpretation of ecological or genomic data (Carini et al. 2013). To close the circle, pure cultures can be used to find exactly these genotypes in nature, to do hypothesis-driven experiments, and to study their geno- and phenotypic traits in depth to get more insights into their ecophysiology (Fig. 4).

\section{TWO EXAMPLES OF A SUCCESSFUL APPLICATION OF THE 'FULL CYCLE ISOLATION APPROACH'}

Ideally, single-cell methods, in situ quantification, phenotypic characterization, and '-omic' approaches should be combined to study the most abundant freshwater microbes. The availability of cultures has accelerated development in several research lines where environmental meta-omics and single-cell methods can hardly achieve sufficient speciesspecific resolution. The examples below describe a successful application of the 'full cycle isolation approach' for 2 ubiquitous betaproteobacterial genera. We briefly summarize the timeline from first discoveries of $16 \mathrm{~S}$ rDNA sequences in clone libraries to a successful targeted isolation based on a mosaic of ecological features that evolved from exploratory studies. Moreover, we report examples of genomic traits, specific substrate utilization, distribution in different environments, and experimental approaches that address questions related to niche separation, vulnerability to different mortality sources, and their role in carbon flow to higher trophic levels.

\section{Limnohabitans spp.}

Environmental 16S rDNA sequences gained from several freshwater ecosystems indicated a ubiquitous distribution of the beta I or 'Rhodoferax sp. BAL47' lineage of Betaproteobacteria (Glöckner et al. 2000, Zwart et al. 2002). These $16 \mathrm{~S}$ rDNA sequences allowed the design of a specific probe for FISH (RBT065, Šimek et al. 2001) that was intensely used. For instance, these bacteria were present in high numbers in a wide range of freshwater habitats, and their abundances were positively correlated to higher $\mathrm{pH}$ and concentrations of low-molecular-weight dissolved organic carbon (Warnecke et al. 2005, Šimek et al. 2010b). Temporal monitoring in single habitats revealed a pronounced seasonality with maxima during phytoplankton blooms in spring (Selje et al. 2005, Grossart et al. 2008, Šimek et al. 2008, 2014, Eckert et al. 2012, Salcher 2014) and/or summer (Salcher et al. 2008, Buck et al. 2009, Pérez \& Sommaruga 2011). Moreover, the FISH probe was also used in various in situ experiments that resulted in first insights in the ecology of Limnohabitans spp. that is characterized by: (1) a rapid growth in response to environmental changes (Šimek et al. 2006, Neuenschwander et al. 2015), (2) a high substrate versatility (Salcher et al. 2013, Rofner et al. 2016a) and uptake rates (Horňák 
et al. 2006, 2008, Salcher et al. 2008, Pérez et al. 2015, Rofner et al. 2016b), (3) a high level of vulnerability to predation by flagellates (Jezbera et al. 2005, 2006, Šimek et al. 2005, 2014), and (4) a strong link to phytoplankton-derived organic material as a key growth substrate (Pérez \& Sommaruga 2006, 2007, Šimek et al. 2008, 2011, Horňák et al. 2012, Paver et al. 2013).

Based on these ecological features, numerous strains of the genus have been brought to culture by targeted isolation. As Limnohabitans spp. are among the fastest-growing microbes in bacterivore-free treatments (plankton samples filtered through $0.8 \mu \mathrm{m}$, Šimek et al. 2001, 2006) they were used to develop a modified filtration-acclimatization protocol (Hahn et al. 2010a,b, Kasalický et al. 2010, 2013): water samples were filtered through a $0.8 \mu \mathrm{m}$ polycarbonate membrane and the filtrate was left for $12 \mathrm{~h}$ at $18^{\circ} \mathrm{C}$, which resulted in an approximate doubling of the rapidly growing target group. The filtrate was subsequently diluted with inorganic basal medium and inoculated onto 24 -well plates $\left(\sim 0.5\right.$ cells well $\left.{ }^{-1}\right)$, and cultures were acclimatized to growth in rich medium by stepwise addition of increasing doses of NSY medium (Hahn et al. 2003). This protocol has facilitated the isolation of more than 45 strains of diverse sizes and morphologies and establishment of the genus Limnohabitans with 4 validly described species to date (Hahn et al. 2010a,b, Kasalický et al. 2010). Although several strains affiliated with Limnohabitans spp. were already isolated earlier, they were not further investigated and not validly described (Page et al. 2004, Gich et al. 2005, Selje et al. 2005).

The intergenic spacer between the $16 \mathrm{~S}$ and $23 \mathrm{~S}$ rRNA gene (ITS) was further used as a fine-scale marker and resulted in the delineation into 5 lineages (LimA, LimB, LimC, LimD, and LimE) and several sublineages within the most diversified lineage LimC (Kasalický et al. 2013). These lineages could also be discriminated by large differences in cell size (0.02-0.9 $\mu^{3}$ cell volume), morphology (coccoid, rods, curved, solenoid, ovoid), and substrate uptake (Kasalický et al. 2013). A profound microdiversification and habitat preference of the different lineages across a large set of freshwater systems was discovered with RLBH probes designed from ITS sequences (Jezbera et al. 2013). Likewise, whole-genome sequencing of 22 strains revealed a large diversity in genome size (2.6-5 Mbp) and genomic traits, e.g. several alternative ways of bacterial phototrophy and $\mathrm{CO}_{2}$ fixation were discovered in some strains of this genus that was formerly assumed to be entirely heterotrophic (Zeng et al. 2012, V. Kasalický unpubl.). One lineage related to L. planktonicus was repeatedly detected as symbionts of Daphnia sp.; thus, not all Limnohabitans spp. live exclusively planktonic (Freese \& Schink 2011, Eckert \& Pernthaler 2014, Peerakietkhajorn et al. 2016). The genus is also not only restricted to freshwaters, as some genotypes occurred in brackish environments (Alonso et al. 2009, Piwosz et al. 2013). Limnohabitans strains have repeatedly been used in experimental studies with simplified microbial communities to assess niche separation among coexisting strains through interactions with particular algal species and their exudates (Šimek et al. 2011), their vulnerability to predation by protists or viral infection, and interspecific interactions with other bacteria (Šimek et al. 2010a, Horňák \& Corno 2012, Hall \& Corno 2014, Salcher et al. 2016). Their role in the carbon flow to higher trophic levels has been studied in detail in experiments using protistan model organisms (Šimek et al. 2010a, Salcher et al. 2016) or natural heterotrophic flagellate communities from different lakes (Šimek et al. 2013, Grujčić et al. 2015). All of these experiments proved that Limnohabitans spp. are of high food quality for protists and have a limited ability to form grazing-resistant morphologies. They thus play an important role in channeling carbon to higher trophic levels in aquatic food webs, although with striking strain-specific as well as season- and site-specific patterns. In summary, the genus Limnohabitans is very diverse, and individual strains differ dramatically in their ecology; however, they also have common features, i.e. fast growth and high importance in microbial food webs. Thus, Limnohabitans spp. represent perfect model organisms for diversified copiotrophs with high environmental relevance.

\section{‘Ca. Methylopumilus spp.'}

Similar to Limnohabitans, the beta IV or LD28 lineage of Betaproteobacteria was also first discovered from environmental 16S rDNA sequences (Zwart et al. 1998, 2002, Glöckner et al. 2000) and frequently recovered thereafter (Newton et al. 2011). The application of a general FISH-probe targeting the whole family (Methylophilaceae) resulted in high numbers of planktonic microbes in hypolimnetic samples, while they were rare in surface samples during summer (Salcher et al. 2008, Jezbera et al. 2012). The development of a specific probe (LD28-1017) proved this spatial distribution (Salcher et al. 2011a). Their 
close phylogenetic relation to planktonic marine (Giovannoni et al. 2008) and freshwater sediment methylotrophs (Chistoserdova 2015) hinted at a methylotrophic lifestyle, i.e. a specialization to $C_{1}$ substrates. Indeed, MAR-FISH revealed no or only a low uptake of amino acids and sugars (Salcher et al. 2008, 2013).

The isolation of a first strain was reported early (Gich et al. 2005), but this strain was not further investigated. Dilution to extinction with sterile filtered and autoclaved lake water as medium and a $0.4 \mu \mathrm{m}$ filtered inoculum resulted in the isolation of $>120$ strains, and the LD28 lineage as well as the closely related PRD01a011B lineage were described as Candidatus ('Ca. Methylopumilus planktonicus' and 'Ca. M. turicensis;' Salcher et al. 2015). A recently modified targeted isolation approach with size fractionation and enrichment in artificial medium containing only methanol and methylamine as carbon sources resulted in a greatly enhanced cultivability of planktonic methylotrophs with $>90$ new isolates from different lakes (M. M. Salcher unpubl. data).

All strains affiliated with 'Ca. Methylopumilus planktonicus' are of conspicuous small cell size (0.02-0.07 $\mu^{3}$, i.e. ultramicrobacteria) and display very slow growth $\left(\mu_{\max }=0.4 \mathrm{~d}^{-1}\right)$. Whole-genome sequencing of several strains revealed very small and streamlined genomes (1.3 Mbp) with a low GC content and a reduced number of genes encoding methylotrophic pathways compared to their relatives from freshwater sediments. Therefore, these microbes follow a typical oligotrophic lifestyle, similar to their marine sister lineage OM43 (Giovannoni et al. 2008). The genomes lacked genes for methylamine oxidation, thus these microbes seemed to be unable to utilize this $\mathrm{C}_{1}$ compound. However, growth of one strain was enhanced upon addition of methylamine to sterile lake water, hinting at so far unknown pathways or genes (Salcher et al. 2015). Genomic sequences of the gene encoding methanol dehydrogenase (xохF) from 'Ca. Methylopumilus spp.' and the marine OM43 were used to search in numerous metagenomes and to develop specific qPCR primers that enabled a quantification of gene numbers and mRNA transcripts in different freshwater, estuarine, and marine habitats (Ramachandran \& Walsh 2015). This gene had a widespread distribution in lakes, rivers, and coastal marine sites, and highest expression coincided with a phytoplankton bloom (Ramachandran \& Walsh 2015). This is in accordance with seasonal monitoring of the abundances of ' $C a$. Methylopumilus sp.' in different lakes, where max- ima occurred concomitantly with blooms of diatoms and/or cyanobacteria (Li et al. 2015, Salcher et al. 2015, Woodhouse et al. 2016), indicating that $C_{1}$ substrates supporting their growth were presumably released from primary producers. Seasonal monitoring also suggested an adaptation to cold water temperatures, a hypothesis that was verified by the observation that cultures reached higher densities at colder incubation temperatures (Salcher et al. 2015). In summary, 'Ca. Methylopumilus spp.' are perfect model organisms for specialized oligotrophs with very reduced genomes, and their close phylogenetic relationship to planktonic marine and freshwater sediment microbes makes them ideal for evolutionary studies regarding genome streamlining, horizontal gene transfer, habitat transitions, and ecological specialization (Walsh et al. 2013, Ramachandran \& Walsh 2015, Salcher et al. 2015, Jimenez-Infante et al. 2016).

\section{CONCLUSIONS AND FUTURE PERSPECTIVES}

We hope that our presented ideas and examples may inspire readers (1) to enrich and isolate planktonic freshwater microbes (Fig. 4), (2) to set up experiments with cultured strains (Fig. 3), and (3) to use fine-resolution '-omics' approaches in combination with classical ecophysiological profiling and in situ methods. Continuing efforts will hopefully result in the successful isolation of more freshwater microbes, especially of those that have thus far been elusive. The 'full cycle isolation approach' for targeted cultivation (Fig. 4) might be a future direction, as the increasingly available tools of (meta-)omics shed more light on the ecology of so far uncultivated taxa which might help to enrich and isolate the target microbes and to design specific media that support their growth.

Acknowledgements. We thank Rohit Ghai and Thomas Posch for discussion and critical comments and 2 anonymous reviewers for helpful suggestions. Financial support was provided by the Czech Science Foundation [CSF grant number 13-00243S].

\section{LITERATURE CITED}

Ali Z, Cousin S, Frühling A, Brambilla E, Schumann P, Yang Y, Stackebrandt E (2009) Flavobacterium rivuli sp. nov., Flavobacterium subsaxonicum sp. nov., Flavobacterium swingsii sp. nov. and Flavobacterium reichenbachii sp. nov., isolated from a hard water rivulet. Int J Syst Evol Microbiol 59:2610-2617 
Allen DA, Austin B, Colwell RR (1983) Numerical taxonomy of bacterial isolates associated with a freshwater fishery. Microbiology 129:2043-2062

> Alonso C, Zeder M, Piccini C, Conde D, Pernthaler J (2009) Ecophysiological differences of betaproteobacterial populations in two hydrochemically distinct compartments of a subtropical lagoon. Environ Microbiol 11:867-876

$>$ Amann R, Fuchs BM (2008) Single-cell identification in microbial communities by improved fluorescence in situ hybridization techniques. Nat Rev Microbiol 6:339-348

Amann R, Ludwig W, Schleifer K (1995) Phylogenetic identification and in situ detection of individual microbial cells without cultivation. Microbiol Rev 59:143-169

Blainey PC (2013) The future is now: single-cell genomics of bacteria and archaea. FEMS Microbiol Rev 37:407-427

Bodrossy L (2015) The full metagenomics cycle. Environ Microbiol 17:4819-4821

> Bruns A, Nübel U, Cypionka H, Overmann J (2003) Effect of signal compounds and incubation conditions on the culturability of freshwater bacterioplankton. Appl Environ Microbiol 69:1980-1989

> Buck U, Grossart HP, Amann R, Pernthaler J (2009) Substrate incorporation patterns of bacterioplankton populations in stratified and mixed waters of a humic lake. Environ Microbiol 11:1854-1865

- Carini P, Steindler L, Beszteri S, Giovannoni SJ (2013) Nutrient requirements for growth of the extreme oligotroph 'Candidatus pelagibacter ubique' HTCC1062 on a defined medium. ISME J 7:592-602

Chistoserdova L (2015) Methylotrophs in natural habitats: current insights through metagenomics. Appl Microbiol Biotechnol 99:5763-5779

> Clingenpeel S, Schwientek P, Hugenholtz P, Woyke T (2014) Effects of sample treatments on genome recovery via single-cell genomics. ISME J 8:2546-2549

> Connon SA, Giovannoni SJ (2002) High-throughput methods for culturing microorganisms in very-low-nutrient media yield diverse new marine isolates. Appl Environ Microbiol 68:3878-3885

> Cordero OX, Polz MF (2014) Explaining microbial genomic diversity in light of evolutionary ecology. Nat Rev Microbiol 12:263-273

> Cousin S, Brambilla E, Yang J, Stackebrandt E (2008) Culturable aerobic bacteria from the upstream region of a karst water rivulet. Int Microbiol 11:91-100

- Eckert EM, Pernthaler J (2014) Bacterial epibionts of Daphnia: a potential route for the transfer of dissolved organic carbon in freshwater food webs. ISME J 8:1808-1819

Eckert EM, Salcher MM, Posch T, Eugster B, Pernthaler J (2012) Rapid successions affect microbial n-acetylglucosamine uptake patterns during a lacustrine spring phytoplankton bloom. Environ Microbiol 14:794-806

> Franzosa EA, Hsu T, Sirota-Madi A, Shafquat A, Abu-Ali G, Morgan XC, Huttenhower C (2015) Sequencing and beyond: integrating molecular 'omics' for microbial community profiling. Nat Rev Microbiol 13:360-372

Freese HM, Schink B (2011) Composition and stability of the microbial community inside the digestive tract of the aquatic crustacean Daphnia magna. Microb Ecol 62: 882-894

> Garcia SL (2016) Mixed cultures as model communities: hunting for ubiquitous microorganisms, their partners, and interactions. Aquat Microb Ecol 77:79-85

- Garcia SL, McMahon KD, Grossart HP, Warnecke F (2014) Successful enrichment of the ubiquitous freshwater acI
Actinobacteria. Environ Microbiol Rep 6:21-27

Garcia SL, Buck M, McMahon KD, Grossart HP, Eiler A, Warnecke F (2015) Auxotrophy and intrapopulation complementary in the 'interactome' of a cultivated freshwater model community. Mol Ecol 24:4449-4459

Ghylin TW, Garcia SL, Moya F, Oyserman BO and others (2014) Comparative single-cell genomics reveals potential ecological niches for the freshwater acI Actinobacteria lineage. ISME J 8:2503-2516

$>$ Gich F, Schubert K, Bruns A, Hoffelner H, Overmann J (2005) Specific detection, isolation, and characterization of selected, previously uncultured members of the freshwater bacterioplankton community. Appl Environ Microbiol 71:5908-5919

> Giovannoni S, Stingl U (2007) The importance of culturing bacterioplankton in the 'omics' age. Nat Rev Microbiol 5: 820-826

- Giovannoni SJ, Hayakawa DH, Tripp HJ, Stingl U and others (2008) The small genome of an abundant coastal ocean methylotroph. Environ Microbiol 10:1771-1782

Glöckner FO, Zaichikov E, Belkova N, Denissova L, Pernthaler J, Pernthaler A, Amann R (2000) Comparative 16S rRNA analysis of lake bacterioplankton reveals globally distributed phylogenetic clusters including an abundant group of Actinobacteria. Appl Environ Microbiol 66: 5053-5065

> González-Torres P, Pryszcz LP, Santos F, Martínez-García M, Gabaldón T, Antón J (2015) Interactions between closely related bacterial strains are revealed by deep transcriptome sequencing. Appl Environ Microbiol 81: 8445-8456

Grossart HP, Jezbera J, Horňák K, Hutalle KML, Buck U, Šimek K (2008) Top-down and bottom-up induced shifts in bacterial abundance, production and community composition in an experimentally divided humic lake. Environ Microbiol 10:635-652

Grujčić V, Kasalický V, Šimek K (2015) Prey-specific growth responses of freshwater flagellate communities induced by morphologically distinct bacteria from the genus Limnohabitans. Appl Environ Microbiol 81:4993-5002

Hahn MW (2003) Isolation of strains belonging to the cosmopolitan Polynucleobacter necessarius cluster from freshwater habitats located in three climatic zones. Appl Environ Microbiol 69:5248-5254

> Hahn MW (2009) Description of seven candidate species affiliated with the phylum Actinobacteria, representing planktonic freshwater bacteria. Int J Syst Evol Microbiol 59:112-117

Hahn MW, Höfle MG (1998) Grazing pressure by a bacterivorous flagellate reverses the relative abundance of Comamonas acidivorans px54 and Vibrio strain cb5 in chemostat coculture. Appl Environ Microbiol 64: 1910-1918

Hahn MW, Pöckl M (2005) Ecotypes of planktonic Actinobacteria with identical 16S rRNA genes adapted to thermal niches in temperate, subtropical, and tropical freshwater habitats. Appl Environ Microbiol 71:766-773

Hahn MW, Lünsdorf H, Wu Q, Schauer M, Höfle M, Boenigk J, Stadler P (2003) Isolation of novel ultramicrobacteria classified as Actinobacteria from five freshwater habitats in Europe and Asia. Appl Environ Microbiol 69: 1442-1451

> Hahn MW, Lang E, Brandt U, Wu QL, Scheuerl T (2009) Emended description of the genus Polynucleobacter and the species Polynucleobacter necessarius and proposal of 
two subspecies, $P$. necessarius subsp. necessarius subsp. nov. and $P$. necessarius subsp. asymbioticus subsp. nov. Int J Syst Evol Microbiol 59:2002-2009

Hahn MW, Kasalický V, Jezbera J, Brandt U, Jezberova J, Šimek K (2010a) Limnohabitans curvus gen. nov., sp. nov., a planktonic bacterium isolated from a freshwater lake. Int J Syst Evol Microbiol 60:1358-1365

> Hahn MW, Kasalický V, Jezbera J, Brandt U, Šimek K (2010b) Limnohabitans australis sp. nov., isolated from a freshwater pond, and emended description of the genus Limnohabitans. Int J Syst Evol Microbiol 60:2946-2950

> Hahn MW, Lang E, Brandt U, Lunsdorf H, Wu QL, Stackebrandt E (2010c) Polynucleobacter cosmopolitanus sp. nov., free-living, planktonic bacteria inhabiting freshwater lakes and rivers. Int J Syst Evol Microbiol 60: 166-173

> Hahn MW, Lang E, Brandt U, Sproer C (2011) Polynucleobacter acidiphobus sp. nov., a representative of an abundant group of planktonic freshwater bacteria. Int J Syst Evol Microbiol 61:788-794

Hahn MW, Minasyan A, Lang E, Koll U, Spröer C (2012) Polynucleobacter difficilis sp. nov., a planktonic freshwater bacterium affiliated with subcluster B1 of the genus Polynucleobacter. Int J Syst Evol Microbiol 62:376-383

Hahn MW, Schmidt J, Taipale SJ, Doolittle WF, Koll U (2014) Rhodoluna lacicola gen. nov., sp. nov., a planktonic freshwater bacterium with stream-lined genome. Int J Syst Evol Microbiol 64:3254-3263

Hahnke RL, Bennke CM, Fuchs BM, Mann AJ and others (2015) Dilution cultivation of marine heterotrophic bacteria abundant after a spring phytoplankton bloom in the North Sea. Environ Microbiol 17:3515-3526

Hall AR, Corno G (2014) Tetracycline modifies competitive interactions in experimental microcosms containing bacteria isolated from freshwater. FEMS Microbiol Ecol 90: 168-174

Horňák K, Corno G (2012) Every coin has a back side: invasion by Limnohabitans planktonicus promotes the maintenance of species diversity in bacterial communities. PLOS ONE 7:e51576

Horňák K, Jezbera J, Nedoma J, Gasol J, Šimek K (2006) Effects of resource availability and bacterivory on leucine incorporation in different groups of freshwater bacterioplankton, assessed using microautoradiography. Aquat Microb Ecol 45:277-289

Horňák K, Jezbera J, Šimek K (2008) Effects of a Microcystis aeruginosa bloom and bacterivory on bacterial abundance and activity in a eutrophic reservoir. Aquat Microb Ecol 52:107-117

Horňák K, Zeder M, Blom JF, Posch T, Pernthaler J (2012) Suboptimal light conditions negatively affect the heterotrophy of Planktothrix rubescens but are beneficial for accompanying Limnohabitans spp. Environ Microbiol 14:765-778

> Hutalle-Schmelzer KML, Zwirnmann E, Krüger A, Grossart HP (2010) Enrichment and cultivation of pelagic bacteria from a humic lake using phenol and humic matter additions. FEMS Microbiol Ecol 72:58-73

Jagmann N, Brachvogel HP, Philipp B (2010) Parasitic growth of Pseudomonas aeruginosa in co-culture with the chitinolytic bacterium Aeromonas hydrophila. Environ Microbiol 12:1787-1802

Jannasch HW (1958) Studies on planktonic bacteria by means of a direct membrane filter method. J Gen Microbiol 18:609-620
Jezbera J, Horňák K, Šimek K (2005) Food selection by bacterivorous protists: insight from the analysis of the food vacuole content by means of fluorescence in situ hybridization. FEMS Microbiol Ecol 52:351-363

Jezbera J, Horňák K, Šimek K (2006) Prey selectivity of bacterivorous protists in different size fractions of reservoir water amended with nutrients. Environ Microbiol 8: 1330-1339

Jezbera J, Sharma AK, Brandt U, Doolittle WF, Hahn MW (2009) 'Candidatus Planktophila limnetica', an actinobacterium representing one of the most numerically important taxa in freshwater bacterioplankton. Int J Syst Evol Microbiol 59:2864-2869

Jezbera J, Jezberová J, Brandt U, Hahn MW (2011) Ubiquity of Polynucleobacter necessarius subspecies asymbioticus results from ecological diversification. Environ Microbiol 13:922-931

Jezbera J, Jezberová J, Koll U, Horňák K, Šimek K, Hahn MW (2012) Contrasting trends in distribution of four major planktonic betaproteobacterial groups along a $\mathrm{pH}$ gradient of epilimnia of 72 freshwater habitats. FEMS Microbiol Ecol 81:467-479

Jezbera J, Jezberová J, Kasalický V, Šimek K, Hahn MW (2013) Patterns of Limnohabitans microdiversity across a large set of freshwater habitats as revealed by reverse line blot hybridization. PLOS ONE 8:e58527

Jimenez-Infante F, Ngugi DK, Vinu M, Alam I and others (2016) Comprehensive genomic analyses of the OM43 clade, including a novel species from the Red Sea, indicate ecotype differentiation among marine methylotrophs. Appl Environ Microbiol 82:1215-1226

> Jogler M, Siemens H, Chen H, Bunk B, Sikorski J, Overmann J (2011) Identification and targeted cultivation of abundant novel freshwater sphingomonads and analysis of their population substructure. Appl Environ Microbiol 77:7355-7364

Kämpfer P, Buczolits S, Albrecht A, Busse HJ, Stackebrandt E (2003) Towards a standardized format for the description of a novel species (of an established genus): Ochrobactrum gallinifaecis sp. nov. Int J Syst Evol Microbiol 53:893-896

Kasalický V, Jezbera J, Šimek K, Hahn MW (2010) Limnohabitans planktonicus sp. nov., and Limnohabitans parvus sp. nov., two novel planktonic Betaproteobacteria isolated from a freshwater reservoir and emended description of the genus Limnohabitans. Int J Syst Evol Microbiol 60:2710-2714

Kasalický V, Jezbera J, Hahn MW, Šimek K (2013) The diversity of the Limnohabitans genus, an important group of freshwater bacterioplankton, by characterization of 35 isolated strains. PLOS ONE 8:e58209

Könneke M, Bernhard AE, de la Torre JR, Walker CB, Waterbury JB, Stahl DA (2005) Isolation of an autotrophic ammonia-oxidizing marine archaeon. Nature 437:543-546

> Lee S, Weon HY, Han K, Ahn TY (2012) Flavobacterium dankookense sp. nov., isolated from a freshwater reservoir and emended descriptions of Flavobacterium cheonanense, F. chungnamense, F. koreense and F. aquatile. Int J Syst Evol Microbiol 62:2378-2382

> Li J, Zhang J, Liu L, Fan Y and others (2015) Annual periodicity in planktonic bacterial and archaeal community composition of eutrophic Lake Taihu. Sci Rep 5:15488

Murray RGE, Stackebrandt E (1995) Taxonomic note: implementation of the provisional status Candidatus for 
incompletely described procaryotes. Int J Syst Bacteriol 45:186-187

Musat N, Halm H, Winterholler B, Hoppe P and others (2008) A single-cell view on the ecophysiology of anaerobic phototrophic bacteria. Proc Natl Acad Sci USA 105: 17861-17866

Neuenschwander SM, Pernthaler J, Posch T, Salcher MM (2015) Seasonal growth potential of rare lake water bacteria suggest their disproportional contribution to carbon fluxes. Environ Microbiol 17:781-795

Newton RJ, Jones SE, Eiler A, McMahon KD, Bertilsson S (2011) A guide to the natural history of freshwater lake bacteria. Microbiol Mol Biol Rev 75:14-49

O'Sullivan LA, Fuller KE, Thomas EM, Turley CM, Fry JC, Weightman AJ (2004) Distribution and culturability of the uncultivated 'agg58 cluster' of the Bacteroidetes phylum in aquatic environments. FEMS Microbiol Ecol 47:359-370

> O'Sullivan LA, Rinna J, Humphreys G, Weightman AJ, Fry JC (2005) Fluviicola taffensis gen. nov., sp. nov., a novel freshwater bacterium of the family Cryomorphaceae in the phylum 'Bacteroidetes'. Int J Syst Evol Microbiol 55: 2189-2194

Page K, Connon S, Giovannoni S (2004) Representative freshwater bacterioplankton isolated from Crater Lake, Oregon. Appl Environ Microbiol 70:6542-6550

Paver SF, Hayek KR, Gano KA, Fagen JR and others (2013) Interactions between specific phytoplankton and bacteria affect lake bacterial community succession. Environ Microbiol 15:2489-2504

Paver SF, Youngblut ND, Whitaker RJ, Kent AD (2015) Phytoplankton succession affects the composition of polynucleobacter subtypes in humic lakes. Environ Microbiol 17:816-828

Peerakietkhajorn S, Kato Y, Kasalický V, Matsuura T, Watanabe H (2016) Betaproteobacteria Limnohabitans strains increase fecundity in the crustacean Daphnia magna: symbiotic relationship between major bacterioplankton and zooplankton in freshwater ecosystem. Environ Microbiol 18(8):2366-74

- Pérez MT, Sommaruga R (2006) Differential effect of algaland soil-derived dissolved organic matter on alpine lake bacterial community composition and activity. Limnol Oceanogr 51:2527-2537

Pérez MT, Sommaruga R (2007) Interactive effects of solar radiation and dissolved organic matter on bacterial activity and community structure. Environ Microbiol 9: 2200-2210

Pérez MT, Sommaruga R (2011) Temporal changes in the dominance of major planktonic bacterial groups in an alpine lake: discrepancy with their contribution to bacterial production. Aquat Microb Ecol 63:161-170

> Pérez MT, Rofner C, Sommaruga R (2015) Dissolved organic monomer partitioning among bacterial groups in two oligotrophic lakes. Environ Microbiol Rep 7:265-272

Piwosz K, Salcher MM, Zeder M, Ameryk A, Pernthaler J (2013) Seasonal dynamics and activity of typical freshwater bacteria in brackish waters of the Gulf of Gdansk. Limnol Oceanogr 58:817-826

- Ramachandran A, Walsh DA (2015) Investigation of XoxF methanol dehydrogenases reveals new methylotrophic bacteria in pelagic marine and freshwater ecosystems. FEMS Microbiol Ecol 91:fiv105

Rappé MS, Connon SA, Vergin KL, Giovannoni SJ (2002) Cultivation of the ubiquitous SAR11 marine bacterio- plankton clade. Nature 418:630-633

> Rinke C, Schwientek P, Sczyrba A, Ivanova NN and others (2013) Insights into the phylogeny and coding potential of microbial dark matter. Nature 499:431-437

> Rodriguez-Valera F, Martin-Cuadrado AB, Rodriguez-Brito B, Pasic L, Thingstad TF, Rohwer F, Mira A (2009) Explaining microbial population genomics through phage predation. Nat Rev Microbiol 7:828-836

Rofner C, Sommaruga R, Pérez MT (2016a) Differential utilization patterns of dissolved organic phosphorus compounds by heterotrophic bacteria in two mountain lakes. FEMS Microbiol Ecol 92:fiw139

> Rofner C, Sommaruga R, MT Pérez (2016b) Phosphate and ATP uptake by lake bacteria: Does taxonomical identity matter? Environ Microbiol (in press), doi:10.1111/14622920.13368

Sack ELW, van der Wielen PWJJ, van der Kooij D (2011) Flavobacterium johnsoniae as a model organism for characterizing biopolymer utilization in oligotrophic freshwater environments. Appl Environ Microbiol 77: 6931-6938

Salcher MM (2014) Same same but different: ecological niche partitioning of planktonic freshwater prokaryotes. J Limnol 73:74-87

Salcher MM, Pernthaler J, Zeder M, Psenner R, Posch T (2008) Spatio-temporal niche separation of planktonic Betaproteobacteria in an oligo-mesotrophic lake. Environ Microbiol 10:2074-2086

Salcher MM, Pernthaler J, Frater N, Posch T (2011a) Vertical and longitudinal distribution patterns of different bacterioplankton populations in a canyon-shaped, deep prealpine lake. Limnol Oceanogr 56:2027-2039

Salcher MM, Pernthaler J, Posch T (2011b) Seasonal bloom dynamics and ecophysiology of the freshwater sister clade of SAR11 bacteria 'that rule the waves' (LD12). ISME J 5:1242-1252

Salcher MM, Posch T, Pernthaler J (2013) In situ substrate preferences of abundant bacterioplankton populations in a prealpine freshwater lake. ISME J 7:896-907

Salcher MM, Neuenschwander SM, Posch T, Pernthaler J (2015) The ecology of pelagic freshwater methylotrophs assessed by a high-resolution monitoring and isolation campaign. ISME J 9:2442-2453

Salcher MM, Ewert C, Šimek K, Kasalický V, Posch T (2016) Interspecific competition and protistan grazing affect the coexistence of freshwater betaproteobacterial strains. FEMS Microbiol Ecol 92:fiv156

> Salka I, Srivastava A, Allgaier M, Grossart HP (2014) The draft genome sequence of Sphingomonas sp. strain FukuSWIS1, obtained from acidic lake Grosse Fuchskuhle, indicates photoheterotrophy and a potential for humic matter degradation. Genome Announc 2:e01183-14

Schut F, Gottschal JC, Prins RA (1997) Isolation and characterisation of the marine ultramicrobacterium Sphingomonas sp. strain RB2256. FEMS Microbiol Rev 20: 363-369

Selje N, Brinkhoff T, Simon M (2005) Detection of abundant bacteria in the Weser estuary using culture-dependent and culture-independent approaches. Aquat Microb Ecol 39:17-34

Šimek K, Pernthaler J, Weinbauer MG, Horňák K and others (2001) Changes in bacterial community composition and dynamics and viral mortality rates associated with enhanced flagellate grazing in a mesoeutrophic reservoir. Appl Environ Microbiol 67:2723-2733 
Šimek K, Horňák K, Jezbera J, Masin M, Nedoma J, Gasol J, Schauer M (2005) Influence of top-down and bottom-up manipulation on the R-BT065 subcluster of $\beta$-Proteobacteria, an abundant group in bacterioplankton of a freshwater reservoir. Appl Environ Microbiol 71:2381-2390

Šimek K, Horňák K, Jezbera J, Nedoma J and others (2006) Maximum growth rates and possible life strategies of different bacterioplankton groups in relation to phosphorus availability in a freshwater reservoir. Environ Microbiol 8:1613-1624

Šimek K, Horňák $K$, Jezbera J, Nedoma J, Znachor $P$, Hejzlar J, Sed'a J (2008) Spatio-temporal patterns of bacterioplankton production and community composition related to phytoplankton composition and protistan bacterivory in a dam reservoir. Aquat Microb Ecol 51: $249-262$

Šimek K, Kasalický V, Horňák K, Hahn MW, Weinbauer MG (2010a) Assessing niche separation among coexisting Limnohabitans strains through interactions with a competitor, viruses, and a bacterivore. Appl Environ Microbiol 76:1406-1416

Šimek K, Kasalický V, Jezbera J, Jezberova J, Hejzlar J, Hahn MW (2010b) Broad habitat range of the phylogenetically narrow R-BT065 cluster, representing a core group of the betaproteobacterial genus Limnohabitans. Appl Environ Microbiol 76:631-639

Šimek K, Kasalický V, Zapomelova E, Horňák K (2011) Alga-derived substrates select for distinct betaproteobacterial lineages and contribute to niche separation in Limnohabitans strains. Appl Environ Microbiol 77 : 7307-7315

Šimek K, Kasalický V, Jezbera J, Horňák K and others (2013) Differential freshwater flagellate community response to bacterial food quality with a focus on Limnohabitans bacteria. ISME J 7:1519-1530

Šimek K, Nedoma J, Znachor P, Kasalický V, Jezbera J, Horňák K, Sed'a J (2014) A finely tuned symphony of factors modulates the microbial food web of a freshwater reservoir in spring. Limnol Oceanogr 59:1477-1492

Smith DP, Thrash JC, Nicora CD, Lipton MS and others (2013) Proteomic and transcriptomic analyses of 'Candidatus pelagibacter ubique' describe the first PII-independent response to nitrogen limitation in a free-living Alphaproteobacterium. MBio 4:e00133-12

Son K, Brumley DR, Stocker R (2015) Live from under the lens: exploring microbial motility with dynamic imaging and microfluidics. Nat Rev Microbiol 13:761-775

Sowell SM, Norbeck AD, Lipton MS, Nicora CD and others (2008) Proteomic analysis of stationary phase in the marine bacterium 'Candidatus Pelagibacter ubique'. Appl Environ Microbiol 74:4091-4100

Staley JT, Konopka A (1985) Measurement of in situ activities of nonphotosynthetic microorganisms in aquatic and terrestrial habitats. Annu Rev Microbiol 39:321-346

Steindler L, Schwalbach MS, Smith DP, Chan F, Giovannoni SJ (2011) Energy starved Candidatus Pelagibacter ubique substitutes light-mediated ATP production for endogenous carbon respiration. PLOS ONE 6:e19725

Stepanauskas R (2012) Single cell genomics: an individual look at microbes. Curr Opin Microbiol 15:613-620

> Stingl U, Tripp HJ, Giovannoni SJ (2007) Improvements of high-throughput culturing yielded novel SAR11 strains and other abundant marine bacteria from the Oregon coast and the Bermuda Atlantic Time Series study site. ISME J 1:361-371
Stocker R, Seymour JR (2012) Ecology and physics of bacterial chemotaxis in the ocean. Microbiol Mol Biol Rev 76: 792-812

Sun J, Steindler L, Thrash JC, Halsey KH and others (2011) One carbon metabolism in SAR11 pelagic marine bacteria. PLOS ONE 6:e23973

Temperton B, Giovannoni SJ (2012) Metagenomics: microbial diversity through a scratched lens. Curr Opin Microbiol 15:605-612

> Thrash JC, Temperton B, Swan BK, Landry ZC and others (2014) Single-cell enabled comparative genomics of a deep ocean SAR11 bathytype. ISME J 8:1440-1451

Tripp HJ, Schwalbach MS, Meyer MM, Kitner JB, Breaker RR, Giovannoni SJ (2009) Unique glycine-activated riboswitch linked to glycine-serine auxotrophy in SAR11. Environ Microbiol 11:230-238

> Vila-Costa M, Sharma S, Moran MA, Casamayor EO (2013) Diel gene expression profiles of a phosphorus limited mountain lake using metatranscriptomics. Environ Microbiol 15:1190-1203

Voget S, Wemheuer B, Brinkhoff T, Vollmers J and others (2015) Adaptation of an abundant Roseobacter RCA organism to pelagic systems revealed by genomic and transcriptomic analyses. ISME J 9:371-384

> Wagner M (2009) Single-cell ecophysiology of microbes as revealed by raman microspectroscopy or secondary ion mass spectrometry imaging. Annu Rev Microbiol 63: 411-429

Wagner M, Nielsen PH, Loy A, Nielsen JL, Daims H (2006) Linking microbial community structure with function: fluorescence in situ hybridization-microautoradiography and isotope arrays. Curr Opin Biotechnol 17:83-91

Walsh DA, Lafontaine J, Grossart HP (2013) On the ecoevolutionary relationships of fresh and salt water bacteria and the role of gene transfer in their adaptation. In: Gophna U (ed) Lateral gene transfer in evolution. Springer, New York, NY, p 55-77

> Warnecke F, Sommaruga R, Sekar R, Hofer JS, Pernthaler J (2005) Abundances, identity, and growth state of Actinobacteria in mountain lakes of different UV transparency. Appl Environ Microbiol 71:5551-5559

- Watanabe K, Komatsu N, Kitamura T, Ishii Y and others (2012) Ecological niche separation in the polynucleobacter subclusters linked to quality of dissolved organic matter: a demonstration using a high sensitivity cultivation-based approach. Environ Microbiol 14: 2511-2525

Woodhouse JN, Kinsela AS, Collins RN, Bowling LC, Honeyman GL, Holliday JK, Neilan BA (2016) Microbial communities reflect temporal changes in cyanobacterial composition in a shallow ephemeral freshwater lake. ISME J 10:1337-1351

Woyke T, Sczyrba A, Lee J, Rinke C and others (2011) Decontamination of MDA reagents for single cell whole genome amplification. PLOS ONE 6:e26161

Yooseph S, Nealson KH, Rusch DB, McCrow JP and others (2010) Genomic and functional adaptation in surface ocean planktonic prokaryotes. Nature 468:60-66

Zaremba-Niedzwiedzka K, Viklund J, Zhao W, Ast J and others (2013) Single-cell genomics reveal low recombination frequencies in freshwater bacteria of the SAR11 clade. Genome Biol 14:R130

Zech H, Thole S, Schreiber K, Kalhöfer D and others (2009) Growth phase-dependent global protein and metabolite profiles of Phaeobacter gallaeciensis strain DSM 17395, a 
member of the marine Roseobacter-clade. Proteomics 9: 3677-3697

Zeder M, Peter S, Shabarova T, Pernthaler J (2009) A small population of planktonic Flavobacteria with disproportionally high growth during the spring phytoplankton bloom in a prealpine lake. Environ Microbiol 11: 2676-2686

Zeng Y, Kasalický V, Šimek K, Koblížek M (2012) Genome sequences of two freshwater betaproteobacterial isolates, Limnohabitans species strains rim28 and rim47, indicate their capabilities as both photoautotrophs and ammonia oxidizers. J Bacteriol 194:6302-6303

Editorial responsibility: Paul del Giorgio, Montreal, Quebec, Canada
Zhao Y, Temperton B, Thrash JC, Schwalbach MS and others (2013) Abundant SAR11 viruses in the ocean. Nature 494:357-360

Zwart G, Hiorns WD, Methé BA, van Agterveld MP and others (1998) Nearly identical 16s rRNA sequences recovered from lakes in North America and Europe indicate the existence of clades of globally distributed freshwater bacteria. Syst Appl Microbiol 21:546-556

Zwart G, Crump BC, Kamst-van Agterveld MP, Hagen F, Han SK (2002) Typical freshwater bacteria: an analysis of available 16s rRNA gene sequences from plankton of lakes and rivers. Aquat Microb Ecol 28:141-155

Submitted: March 21, 2016; Accepted: July 18, 2016 Proofs received from author(s): September 8, 2016 